\title{
Jeremiah 33:15-16 as a \\ reinterpretation of Jeremiah 23:5-6
}

\author{
W J Wessels \\ University of South Africa
}

\begin{abstract}
Jeremiah 33:15-16 as a reinterpretation of Jeremiah 23:5-6
\end{abstract}

There are striking similarities between Jeremiah 23:5-6 and Jeremiah 33:15-16. A comparison, however, also shows interesting differences and 33:14-26, furthermore is lacking in the Septuagint tradition. Jeremiah 33:15-16 seems to be a reinterpretation of 23:5-6. This is done by generalising the content, widening the perspective and shifting the emphasis, for instance, from the king to the city, and adding a legitimate heir of David and a legitimate priest. As far as social context is concerned, Jeremiah 33:15-16 should perhaps be linked to the conflict between the disenfranchised Levites and the Zadokites who displaced them. The reinterpretation process is an attempt both to explain the non-fulfilment of 23:5-6 and to resolve the dissonance it creates.

While studying the text of Jeremiah 23:5-6, I noted a parallel passage in Jeremiah 33:15-16 which appeared to be a quotation of the former two verses. On investigating the similarities I discovered, not only some interesting differences, but the fact that the entire pericope of Jeremiah 33:14-26 is missing from the Septuagint (LXX). This raised a number of questions. Why does the passage not occur in the LXX? Whence the differences? Do they tell us anything about the social dispensations from which the two passages arose? Are these passages intended to rationalise or legitimise something, is the one a reinterpretation of the other? Does the fact that both passages occur in the same book tell us anything about how the tradition dealt with the prophetic word? 
I shall try to suggest provisional answers to these questions by reading the text as a product of the society in which it arose (in other words, from an ideological critical point of view) and also by noting whether the text suggests any attempt to resolve cognitive dissonance. Carroll (1979:86-110) wrote a number of articles and other publications based on Leon Festinger's theory of cognitive dissonance. It means, in general terms, that disparities arise between principles and actions or between expectation and reality (e g smoking is harmful but the smoker persists). The theory is based on the conflict between cognitive elements. At a first glance it may seem simplistic, but the complexity and stratification of society should be borne in mind when conflict between cognitive elements produces dissonance. It may be resolved in various ways: (a) ignoring it, (b) rethinking the cognitive elements, (c) finding justification by bringing others around to one 's point of view, or (d) rationalising it. The social group (say, the church) plays a vital supportive part in the process (Carroll 1984:381-391).

A critical step in applying this theory to the unfulfilled prophecies of the Old Testament is to discover how the dissonance (expectation:non-realisation) has been handled, or the reaction of people to the conflict between cognitive elements. Relevant options relieving dissonance would be (a) adjusting the offending elements, (b) reinterpreting the prophecy or (c) defending it by rationalisation. The dissonance may also be ignored. An example of adjustment: the false prophets in Jeremiah initially denied that there would be an exile, but when it came to pass they shifted their ground by saying that it would be brief ( $\mathrm{Jr} 27-29)$. One way of explaining the non-fulfilment of prophecies was by blaming it on the people's sinfulness and refusal to repent. Carroll (1984:390) sees this impenitence as a potent means of explaining the dissonance arising from numerous unfulfilled prophecies of salvation (e g Am 9:11-15; Hs 2:14-23; Is 9:2-7; 11:1-9; 35; Jr 23:5-6; 31:27-33; 33:12-26; Ezk 34:23-31; 37:15-28; Mi 5:2-6; Hg 2:21-23).

Not all Old Testament texts can be read in this way. Research is in any case limited to the available texts, which need to be interpreted very accurately by sophisticated hermeneutic means. There are no absolute answers, only possible explanations of events. Hence the reconstruction of a text by reading it from a specific angle is purely provisional, and sometimes it can be read in more than one way. It is in this hermeneutical framework that I shall investigate Jeremiah 33:15-16 as a parallel to 23:5-6. I shall first comment on the text of the book of Jeremiah, then discuss the two pericopes 23:5-6 and 33:15-16 in their contexts, and finally compare the two. I shall then attempt to make certain inferences from the framework I have used and to suggest answers to the questions that have been posed. 


\section{THE TEXT OF JEREMIAH}

The passages dealt with in this paper Jeremiah 23:5-6 and 33:14-18, have been chosen because 23:5-6 and 33:15-16 are parallel texts. At a first glance 33:15-16 looks like a direct quotation of 23:5-6, but closer scruting reveals unmistakable differences as well as close similarity. It is also a moot point which is original and which is secondary. A vital element in the debate is the absence of 33:14-26 from the Septuagint. This brings into play the entire complex problem posed by the text of Jeremiah (cf Soderlund 1985:11-13).

Research has shown that there were more than one edition of the text of Jeremiah (Tov 1978:52-68). There is talk of an earlier and better tradition of the Jeremian text (a Hebrew Vorlage), on which the LXX is based, and a second more expanded edition of the text which developed into the Masorete Text (cf Janzen 1973:172-173; Carroll 1986:51). This theory was furthered by Tov (1985:211-237) who is of opinion that this so-called Hebrew Vorlage was subjected to a Deuteronomistic redaction before being used for the LXX translation. Some original Jeremian words, absent from the first edition, have been inserted in the second. One such original passage added by the second redactor is Jeremiah 33:1426, with which we are concerned in this paper. According to Tov, the onus of proving that this passage is not Jeremian is on the person who denies its authenticity. A post-exilic date is assigned to the completed second edition. If we agree with Tov that Jeremiah 33:14-26 is authentic, a date approximating the Exile (586 B C) is feasible. According to Janzen (1973:123) Jeremiah 33:14-26 was added to the proto-Masoretic text after the divergence of the second textual traditions (LXX and MT). It is difficult to assign a date to this event, but it must have happened before the completion of the MT text - Tov's second Hebrew edition. An important conclusion to be drawn from the research of Tov and others is that the late date assigned to Jeremiah 33:14-26 because of its omission from the Septuagint should not be taken for granted. What that omission does imply, is that Jeremiah 33:15-16 is secondary in relation to Jeremiah 23:5-6. A date somewhere between the Hebrew Vorlage and the completion of the second Hebrew edition (MT) may therefore be assigned to Jeremiah 33:14-26. Other factors, if any can be found, will have to assist in dating this pericope.

As mentioned before a comparison of the two pericopes under discussion yields many similarities, but also noteable differences of which the reader should aware himself. In section 2 and 3 of this paper $I$ intend to consider each pericope in its respective context. 


\section{JEREMIAH 23:5-6}

Jeremiah 23:5-6 consists of Jeremian words from the period of Zedekiah.

When Jeremiah 23:5-6 is compared with the preceding and following pericopes, it is seen to form a separate unit in terms of:

- introductory formula (cf Jr 9:24;21:27, 30; 33:14);

- change of subject;

- change of style - Jeremiah 23:5-6 is poetical in nature (cf Rudolph 1968:145-146; Weiser 1969:196);

- cohesiveness of content ( $\mathrm{cf}$ Wessels 1985:126-127 for a detailed dicussion of the demarcation of this pericope).

Jeremiah 23:5-6 is a prophecy of salvation, fits syntactically well and is transmitted as a unit.

Literary criticism is needed to establish whether 23:5-6 is Jeremian. Verse 5 is introduced by the expression הנה ימים באים נאם-יהוה, which is a common one in the Old Testament:

(cf 1 Samuel 2:31; 2 Kings 3:20; 20:17; Isaiah 39:6 Jeremiah 51:47);

(cf Jeremiah 7:32; 16:14; 19:6; 13:7; 48:12; 51:52);

(cf Amos 4:2; 8:11; 19:13; Jeremiah $31: 38$;

הנה יםים באים נאם- יהוה (cf Jeremiah 9:24; 31:27, 30; 33;14; 49:2).

Obviously this introduction is a common one in pre-exilic texts (those that are italicised) and was probably known to Jeremiah. He uses it in prophecies of both salvation and doom (Van Selms 1972:278).

The word צמח occurs in the post-exilic text, Isaiah 6:2 (Wildberger 1972:154) and in Zechariah 3:8; 6:12, which date back to about 520 B C ( Fohrer 1969:506). These references agree in referring to a future ruler, but they differ in that Zechariah applies the word to Zerubbabel as the descendant of David, whereas Isaiah speaks of 'the branch of the Lord'. The Jeremian reference has no Messianic connotations: it simply refers to a future ruler. The root שכל (Hi) is used in 
Jeremiah 10:21; 20:11 and 3:15. The former two are Jeremian (Rudolph 1968:75, $129)$ and so, probably, is Jeremiah 23:5.

When it comes to the expression משפט רצדקה, it seems to occur in exilic and post-exilic texts (cf Wessels 1985:60-63), and therefore the literary evidence is inconclusive as to the Jeremian origin of 23:5.

It is possible in terms of the way the verb $\mathrm{NW}(\mathrm{Ni})$ is used in the Jeremian passages $4: 14 ; 8: 20$ and 17:14 that Jeremiah may have used it in 23:6 as well (Rudolph 1968:33, 65, 117). שכן לבטח is used in Deuteronomy 33:12, Psalm 16:9 and Jeremiah 33:16, and in Deuteronomy 33:28 and Proverbs 1:33 it is used without 3. Fohrer considers Psalm 16:9 to be post-exilic and Schmidt regards Deuteronomy 33 as post-Deuteronomistic, which points to the Exile (587 B C). Proverbs 1:33 too, is probably post-exilic (cf Fohrer 1969:309, 348; Schmidt 1982:125). In the light of all this evidence, the use of this form in Jeremiah is not easy to explain, but in view of the parallel drawn in verse 6a between Judah and Israel, it is probably authentic.

Jeremiah 23:5-6 is a prophecy of salvation which forms a single unit both syntactically and in terms of subject matter. The literary quality does not rule out the possibility that these verses are Jeremian, and the fact that they are poetry makes Jeremian authorship more likely.

Jeremiah 23:5-6 are the final verses of conclusion of the cycle of kings (Jr 21:123:6). An independent unit, they are none the less closely related to the preceding pericope (Jr 23:1-4). These four verses speak in general terms of the 'shepherds' the Lord will set over his people; Jeremiah 23:5 makes the prospect concrete by referring to the new king to be raised up by Yahweh (קוD Hi).

The familiar introductory formula emphasises the certainty that the subsequent pronouncement will be fulfilled (Van Selms 1972:278). No exact time is indicated: it is simply a future event. When that time comes, the Lord will raise up a branch for David who will reign as king. However, 'branch' is qualified by the term Pרצ. A number of exegetes consider that this expression may refer to the authenticity or legal rightfulness of this person's claim to the throne of David (Weiser 1969:198;

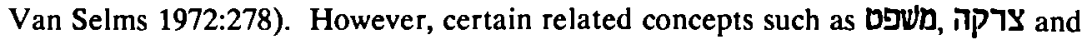
his name, make it more likely that the term refers to the nature of his government: his justice (Rudolph 1968:146). Verse 5 goes on to say that he will rule with wisdom and will excercise justice (מטכ) and righteousness (צרקה). Jeremiah implies that the ruler will maintain the social order and will be trustworthy (Wessels 1985:54-60). This reference harks back to Jeremiah 22:15, which emphasised the nature of a true king's rule. It is tautologically stated that he will reign as king (verb מלך, noun מלך). The implication seems to be that a person who rules as king is not necessarily seen as a king. The new ruler will reign as a true king and be perceived as such. 
Verse 5 forms a unity with verse 6 , referring to a future in which the new king will govern. During his reign Judah will be saved and Israel will dwell securely. Verse 6a contains two parallel, non-identical elements, and the reference to Israel may therefore be taken to mean the restoration of the northern realm.

Jeremiah is therefore saying that the new king will rule over both Judah and Israel, since Judah will be saved and Israel will dwell securely. Because the reference is to Judah and Israel, באר (verse 5) must be translated as "in the country' and not 'on the earth' (Rudolph 1968:145-146). This reference is reminiscent of chapters 30 and 31 , which deal with the restoration of the whole of Israel (Thompson 1980:490). Under the new king, a united Israel will live independently and at peace .

The new king will be named 'The Lord is our righteousness'. According to Rudolph, this name should be regarded like other personal names that contain an element of the name of God (such as Joel or Uzziah) and does not imply the divinity of the Messiah (Rudolph 1968:147). It expresses the peoples' conviction that Yahweh is the actual source of salvation (Weiser 1969:199).

Chapter 23:5, which refers to a branch of David, would appear to contradict Jeremiah 22:30. According to verse 30, no-one of the house of Jehoiachin will sit on the throne of David. Jeremiah appears to be announcing the end of the dynasty. Rudolph (1968:145) disagrees: the house of Jehoiachin is barred from the throne, but there are others who can perpetuate the line of David ( $\mathrm{Jr} 41: 1$ ). This interpretation is not at all far-fetched, but probably Jeremiah meant something slightly different. Jeremiah 23:5-6 concludes a cycle which makes it clear that the kings of David's line have failed. The failure and exile of Jehoiachin was the final disappointment which caused Jeremiah to lose all hope of a successful heir. Jeremiah 23:1-2 goes further by pronouncing judgment on the leaders of Zedekiah's time because they had not guided the people aright. The monarchy had failed and Yahweh was forced to intervene. This provides a clue to the expression "branch of David'. The new king will be raised up by Yahweh.

Chapter 23:3-4 already make it clear that a new era will dawn in which Yahweh will gather the people, appoint new 'shepherds' (including the new king) and unite Judah and Israel. It may well be Jeremiah's ideal of a united realm that produced the idea of a 'branch for David'. David was the king who, once before, had unified the northern and southern realms; to Jeremiah he symbolises a united realm. At some future time Yahweh will appoint a king who, like David, will reunite the two realms and govern according to the behests of Yahweh. In this sence such a king will represent a 'new' Davidic generation. Yahweh makes a fresh beginning with his people and also with the monarchy. The new king's rule over the united Israel will 
be such that the true ruler will be Yahweh himself, and the king's name will proclaim this fact. Up to then the people had determined the selection of the king, but the true king will be selected by Yahweh. We see such a selection by Yahweh illustrated in Deuteronomy 17:15 - the command to the people to appoint the king chosen by Yahweh - and the description in 1 Samuel 10 of the anointing of Saul (cf verse 24).

Carroll (1986:447) considers it possible that 23:5-6 is a prophecy referring to Zedekiah. According to him Zedekiah's name is incorporated into a play on words expressing future expectations. There is probably an allusion to Zedekiah's name and reign, since he was the choice not of the people but of Babylon. However, Zedekiah was not a strong king and was often overruled by his officials ( $\mathrm{Jr}$ 37:17; 38:16, 24-25). By contrast, the true king of the new era will be appointed by Yahweh and, unlike Zedekiah, will rule with wisdom and justice. Yahweh will raise up a king who will be the opposite of the present weak ruler. Jeremiah, it seems, is not using the expression באים ימים in its eschatological sense but simply to refer to a future time. However, eschatology may be defined as faith in the future (Carroll 1982:48) or the evolution of history or even '...the new and the entirely other (occurring) after a break with what has gone before' (Hanson 1979:11; cf also Hanson 1985:468). I shall be using it in this sense. It has to do with real history, real politics and real people are involved.

Jeremiah 23:5-6 reflects Jeremiah's vision of true kingship and also the reasons for his opposition to the kings in the cycle (Jr 21:1-23:6). He sees the true king as someone chosen by Yahweh, who will rule in such a way that Yahweh himself will be the ruler. He will be wise, reliable and just, and during his reign Israel will be united, independent and at peace. In this sense he will be a 'true' king of the line of David. Jeremiah is saying in 23:5-6 that the future of the monarchy rests with Yahweh.

Jeremiah 23:5-6 suitably concludes the cycle of kings that began in Jeremiah 21: 11 and shows that, despite overwhelmingly negative pronouncements, Jeremiah does see a positive future for the monarchy when Yahweh raises up a new king for a new era.

\section{JEREMIAH 33:14-26}

Jeremiah 33:14-26 falls into three parts: verses 14-18, 19-22 and 23-26. The pericope probably dates back to the late exilic or early post-exilic period.

A few remarks about the delineation of the three passages. Verse 33:14 must be the beginning of a new passage, because 33:14-26 does not appear in the Hebrew 
manuscript on which the Septuagint is based. Verse 14 moreover begins with an introductory formula which frequently heralds a new unit in the book of Jeremiah (cf 31:27, 30). Verse 19, which introduces the second part, also starts with a typical formula (33:19 - a word from God; cf Jr 1:4; 32:26; 33:23; 35:12 and 43:8). It also introduces the third part in verse 23 . In addition, the content of each of these three sections supports the unity of the whole section introduced by the formulas.

Verses 15 and 16 of the first part, 33:14-18, appear to correspond very closely to 23:5-6, making it essential to compare the Hebrew text of these two pericopes.

An analysis of 33:14-18 indicates the following: The expression 'I will fulfil the promise' also occurs in Jeremiah 29:10, where it refers to the return of the exiles after seventy years in Babylon. The time in question is therefore a period after the return from exile, probably the same time to which 23:5ff refers. The expression 'in those days' in verse 15 refers to the 'days' of verse 14 and is a vague, general one denoting some future period, in this context probably post-exilic. According to Weiser (1969:306) the expression emphasises the distance in time. ההם באים occurs frequently in Jeremiah, often to express a time of grace (cf 3:16, 18; 31:29; in 50:4, 20 the full expression בימים ההמה ובעח ההיא appears as a time of judgement of Babylon for the salvation of Judah and Israel - cf also Jl 4:1; Zph 3:20 and Dn 11:1, where we find בעת ההיא). It is therefore a term most often used eschatologically to predict salvation for Israel.

The word צמח occurs in the post-exilic text Isaiah 4:2 and in Zechariah 3:8; 6:12, which date back to about 520 B C (Wildberger 1972:154; Fohrer 1969:506). It is therefore possible, provided the passage is Jeremian, that this term was first used in Jeremiah 23:5. There appears to be a link between the use of צמ by Jeremiah and the continuation of this tradition in Haggai and especially in Zechariah. The expression משפט וצרקה is a common one in the Old Testament, and in twelve cases (2 Sm 8:15; 1 Ki 10:9; Jr 22:15; 23:5; 33:15; Ps 99:4; 1 Chr 18:14; 2 Chr 9:8; Is 9:6; 16:5; Jr 22:3; Ezk 45:9) it refers to how a king rules or ought to rule.

Verse 33:17 uses the combination כרו . לאי יכרת לדור in the Qal appears in 2 Chronicles 7:18, but in 1 Kings 2:4; 8:25; 9:5; 2 Chronicles $6: 16$ and 7:18 it appears in the Ni. Rudolph (1968:217) sees it as an application of the Deuteronomistic formula referring back to 2 Samuel 7:16. Verse 17 ends with the expression איש ישב על-כסא ביח- ישראל. The normal Jeremian expression is איש על-כסא רור ריש and occurs in Jeremiah 22:2, 30; 27:25; 29:16 and 36:30. In most cases they probably derive from the Deuteronomist (Smend 1981:159). In Jeremiah 33:17 the expression is somewhat different in that it refers to 'the throne of the house of Israel'. That is exactly the same expression that was applied to the original Davidic dynasty (cf $1 \mathrm{Ki} 2: 4 ; 8: 25 ; 9: 5 ; 2 \mathrm{Chr} 6: 16 ; 7: 18$ ). It was probably 
changed to restore the broader perspective of Israel (hence Judah and Israel) after the exclusive focus on David. The succession of the Davidic dynasty ensures the survival of the realm of Israel .

Verse 18 contains the expression רלכהנים הלרים (which also occurs in Dt $17: 9,18 ; 18: 1 ; 24: 8 ; 27: 9$; Jos 3:3; 8:33; Ezk 43:9 and 44:15) which Carroll regards as Deuteronomistic (Carroll 1986:637). The asyndetic use of the expression in verse 21 is unique: its normal form is as in verse 18 . The reference to offerings in verse 18 is strongly reminiscent of Jeremiah 17:26, in the Deuteronomistic shaped pericope about the Sabbath in Jeremiah 17:19-27. According to Wilson $(1980: 18,235)$, the Levites were the carriers of Ephraimite (northern) traditions. Deuteronomic law (Dt 18:6-8) did not oblige all Levites to function as priests: it impart that they were free to sacrifice at the central sanctuary if they wished. Deuteronomic law did de jure, confer a priestly role on the Levites, but this was never realised de facto (De Vaux 1968:364).

The pericope states that at some future time (no exact time is mentioned, but probably after the Exile and possibly before the rebuilding of the temple), Yahweh would fulfil his promise as recorded in 23:1-6. At the time of writing there was no king of David's line, and sacrificial practices were abnormal - hence the hope of restoration. At the appointed time a lawful branch of David would be raised up, and the important thing about him was not that he would reign (cf 23:5), but that he would bring about justice and righteousness. It would also be a time of peace, and Jenusalem would be named 'The Lord is our righteousness' in strong contrast to the city's miserable past $(\mathrm{Jr} 5 ; 13: 27)$. The reference to the city is in line with the restoration emphatically announced in Jeremiah 33:4-13 (cf 33:4, 5, 6, 9, 10 and 13). An interesting point is that the cycle on the kings in Jeremiah $21: 1 \cdot 23: 8$, which criticises the royal house, contains several prophecies of the destruction of Jerusalem (Jr 21:1-10;22:1-9). The cycle makes it clear that the fate of the royal house was closely linked to that of the city and community (Ackroyd 1972:61). The same trend crops up in 33:4-13 and 14-16, which mention the royal house, the city and the realm.

Verse 17 expatiates on verses 15-16, stating that a physical descendant of David would sit on the throne of the house of Israel. As we have seen, the perspective broadens from the survival of the house of David to that of the realm. To reinforce the survival, it is added that there will always be Levitical priests to bring offerings in the Lord. The house of David and the Levitical priests will be permanent features of society at that time. The Levitical priests will not be excluded from the sacral duties (cf Dt 18:6-7). It seems therefore that Jeremiah 33:14-18 envisages a restoration of the cultic community and not just the king. 
Excursion: The Levites

According to Deuteronomic tradition (Dt 17:9, 18; 18:1; 24:8; 27:9), Levitical priests served at the sanctuary in Jerusalem. At one stage a distinction was made between the latter group and those Levites who served in rural areas (De Vaux 1968:360366). As a result of Josiah's reforms and the centralisation of the cult in Jerusalem, the Zadokites came to control the temple priesthood and the Levites were relegated to a subordinate place. The Zadokites abolished Deuteronomic law; just before the exile of $586 \mathrm{~B} \mathrm{C}$ they legalised the distinction between themselves and the Levites and claimed the priesthood (Hanson 1979:222). During the Exile there was a clear distinction between priests and Levites which by the time of the Chronicler had become an undisputed fact (De Vaux 1968:387, 391). It is interesting that the Zadokites have claimed the Levitical priesthood, as is clearly apparent in their redaction of certain passages in Ezekiel (40:46b; 43:19; 44:15-17; 48:1 and so forth; Hanson 1979:267).

The author of Jeremiah 33:18 would appear to be harking back to a dispensation in which 'priest' and 'Levite' still denoted a single office, or at any rate an equality of office as generally reflected in Deuteronomy - though the separation is there beneath the surface (De Vaux 1968:364). Apart from Deuteronomy, Joshua and Ezekiel, to which we have already referred, Levitical priests are also mentioned in 2 Kings 5:5; 23:18 and 30:27. At the time of the Chronicler the conflict between Levites and Zadokites had subsided somewhat, and the books of Chronicles reflect a more tolerant attitude. In general the references is to priests and Levites (southern $P$ tradition) but occasionally, as we have seen, to Levitical priests (northern Deuteronomic tradition; cf Hanson 1979:269-273).

It is tempting to read Jeremiah 33:14-18 against a Chronicler backdrop. The writer of Chronicles favoured the priest/king dyarchy and set great store by the restoration of Jerusalem as does Jeremiah 33:16. Steck (1968:452-453) is of the opinion that the Chronist emphasises the cult of Jerusalem. He is genuinely interested in the royal line of David, and he respects the royal office but not in messianic terms. The Levites, too, he mentions with respect and honour. Clearly, all the elements emphasised in Jeremiah 33:14-18 would fit into the context of Chronicles. Such a reconstruction is not impossible, but there are two other points of interest. In the first place, Jeremiah 33:14-18 is eschatological and refers to some future time, emphasising its futurity (בימיס הדסי). Seen as part of the Chronicler, Jeremiah 33:14-18 would have to be regarded as already realised in some sense: the reference to the future would be out of place. Secondly, the book of Chronicles refers to Levitical priesthood only three times but repeatedly speaks of priests and Levites: clearly they are more often seen as separate. The emphasis is on the 
functions of Levites as doorguards, singers, teachers and the like, though on occasion they might offer a sacrifice (2 Chr 30:17). Read against a Chronistic backdrop, the ideal spoken of in Jeremiah 33:14-18 becomes that of an insignificant faction or tradition that clung to the Levitical priesthood (Carroll 1986:639).

Another possibility - the one I favour myself - is to read Jeremiah 33:14-18 against a background of conflict between Zadokites and the wronged Levites. The first indication would be the qualification of priests as Levites in verse 17. The conflict had a long history, especially after Josiah had centralised the cult and encouraged Zadokite control of the temple in Jerusalem, but the conflict was fiercest in the exilic and post-exilic period.

As we have seen, the Zadokites ignored Deuteronomic law and formulated new laws to legalise the distinction between priests and Levites (cf Nm 3:6; 8:19; 18:3637 - probably based on a Zadokite formulation immediately prior to the Exile; (cf Hanson 1979:209-222). Jeremiah 33:14-18 should probably be seen as the utterance of a group of Levitical sympathisers living at a time when there was no king. Furthermore they are in no position to exercise the sacrificial functions of priests, since they look forward to a future time when these functions will be restored. Either the temple does not exist, or they are debarred from priestly sacrifice. Probably one could set a time near the end of the Exile, when the 'promise' of Yahweh would come true (cf Jeremiah 33:14). The Zadokites planned once they returned to rebuild the temple and control the Palestinian cult, and their plans did not include the Levites. This may also have predated the redaction of portions of Ezekiel (cf Ezk 44:4-31). The Zadokites' reference to themselves as 'Levitical priests, sons of Zadok' (Ezk 44:15, for example) indicates that they found it necessary to claim Levitical priesthood in the teeth of another group (the 'true' Levitical priests). The tracing of the Zadokite family tree right back to Phinehas and even Aaron also suggests a legitimation of their position (Hanson 1979:271). It was moreover characteristic of the wronged Levites and visionary groups that hardship and injustice inclined them towards eschatology and, later on, apocalyptics. They lived in the expectation that Yahweh would personally intervene to bring new things to pass (cf Deutero-Isaiah and Jeremiah - a new covenant, a new exodus, a new Moses; (cf Hanson 1979:218). The more earthly, realistic approach of the Zadokites disregard of eschatology and their under-emphasising of a Davidic ruler suggest that this pericope is the utterance of a Levitical priestly circle rather than a Zadokite interest group (Hanson 1979:270, 284).

Another factor that points to a Levitical origin for Jeremiah 33:14-18 is the mention of a king who would promote justice, and of Levitical priests in the same context. According to Deuteronomy 17:14-20 (the royal law), the law that pre- 
scribed the king's role was in the keeping of the Levitical priests. (Polk 1979:4 sees the Levites as spokesman of the Mosaic covenant tradition.) Jeremiah 33:14-18 also fits into this Deuteronomic concept (Wilson 1980:160). Like Jeremiah 33:22, the exilic texts Ezekiel 34:23-24 and 37:24-25 speak of David as the servant of the Lord and probably refer to Zerubbabel, who is called both צמד (cf Zch 3:8-10; Blenkinsopp 1984:184). A late exilic or early post-exilic dating is further supported by the link between creation theology (Judean tradition) and salvation history (northern tradition) which we find in Jeremiah 33:23-26. The link between these two motifs, creation and salvation, also occurs in Deutero-Isaiah, where it is used to console the exiles: Yahweh is still in control of world history. Weippert regards Jeremiah 33:23-26 as a post-exilic exegesis of the Jeremian creation concept (Weippert 1981:46).

All these considerations suggest a late exilic or early post-exilic date and a Levitical origin for Jeremiah 33:14-18.

\section{COMPARISON OF JEREMIAH 23:5-6 AND JEREMIAH 33:14-16}

\subsection{Formal aspects}

In a formal sense the two pericopes differ a good deal. By reading the two sections side by side, the similarities and differences are obvious. In terms of context Jeremiah 23:5-6 comes at the end of a cycle dealing the kings (Jr 21:1-23:8) and places the prophets' criticism of the kings in the framework of a specific expectation. In a sense these verses are the climax of the cycle of kings. Jeremiah 33 in turn forms part of a series of salvation prophecies in chapters 30-33. The section 30-31 is often referred to as a 'booklet of Comfort', and chapters 32 and 33 link up with it. Jeremiah 33 is devoted to the rebuilding of Jerusalem (verse 2,13 ) followed by the restoration of the Davidic dynasty. Jeremiah 33:14-26 was probably included in the section on salvation (ch 30-33) because the latter contained no detailed rendering of the restoration of the Davidic line (cf the mere references in Jr 30:9, 21) and the cult was left disorganised. The expanded Masoretic text used Jeremiah 33:14-26 to supply this deficiency (the LXX does not have it). Another difference is that Jeremiah 23:5-6 is poetical, whereas 33:14-16 is more prosaic. Both passages fit my definition of eschatology.

\subsection{Time and situation}

Jeremiah 23:5-6 probably dates from the time of Zedekiah - the end of the monarchy. The king was still on his throne, the temple was still in use and 
Jerusalem and its inhabitants were as yet unscathed. The Babylonians were threatening the city, which gives us a date immediately prior to $586 \mathrm{~B} \mathrm{C}$. I have tried to show that Jeremiah 33:14-16, on the other hand, derives from a late exilic, early post-exilic period - no king, no temple, Jerusalem devastated and neglected and the cream of the nation in exile. It was a time of hardship and internal conflict (cf Levites and Zadokites). A point of similarity between the two sections may be that both express disappointment (Jeremiah's disappointment in the kings, the people in their situation). Moreover, Jeremiah 23:5-6 is Jeremian whereas 33:15-16 is an interpretation and actualisation of Jeremiah's words.

\subsection{Theological content}

As I have indicated, both passages fit the definition of prophetic eschatology I follow. In Jeremiah 23:5-6 the future era of the new Davidic king is represented as a time of salvation: there is a direct link between salvation and the person of this king (cf the expression 'in his days'). In Jeremiah 33:15-16 the reference is a more general one - 'in those days'. A distance in time is implied. A time of salvation is coming in which the king will play a definitive part. Jeremiah 33:15 does not emphasise the nature of his rule as Jeremiah 23:5 does. The same difference is apparent in the application of the name 'Yahweh in our righteousness' to the city of Jerusalem rather than to the branch (king). The new name will apply to Jerusalem as the seat of temple and palace, and as a symbol of survival for the people and realm. The perspective in Jeremiah 33:15-16 expands the expectation that salvation will be realised. Jerusalem - described by Jeremiah as a doomed city (e g Jeremiah $5 ; 13: 28$ ) will be changed and become known as 'Yahweh is our righteousness'. It will be ruled by a king of David's line who will see to it that justice and righteousness prevail .

The wider context of Jeremiah 33:14-18 also differs from that of Jeremiah 23:56. The Levitical priest is a further element in the expectation of the time of salvation (Jr 33:17-18). The latter envisages a future in which there will be a legitimate Davidic monarch and a legitimate (Levitical) priest. Not the monarchy only ( $\mathrm{Jr}$ 23:5-6) but the cult of Jerusalem will be restored. The emphasis is on the restored cultic community of which the king and priesthood form part. I have argued that Jeremiah 23:5-6 suggests a king like David (especially in the light of $\mathbf{J r}$ 22:30), whereas Jeremiah 33:17-18 seems to point to an actual king (Zerubbabel) of the line of David (cf the strong emphasis given by linking it with a covenant in $\mathbf{J}_{\mathbf{r}}$ 33:25-26). In other words, Jeremiah 23:5-6 envisages a completely new creation in the raising up of a branch for David; in Jeremiah 33:14-18 the new creation lies in the restoration of specific ancient structures (a legitimate heir of David, a legitimate 
Levitical priest). Both passages agree that it is Yahweh who will bring it about.

A final point, the matter of Levitical priests. I have submitted that Jeremiah 23:5-6 was written by Jeremiah himself, whereas Jeremiah 33:14-18 probably derives from a Levitical circle. Jeremiah - a native of the priestly city of Anathoth probably sympathised with the Levitical priesthood at a certain stage. If Wilson is correct in saying that the Levites were carriers of the northern tradition in which Shiloh played an important part, many of the northern influences he detects in Jeremiah's proclamation may well be of Levitical origin (cf Wilson 1980:18 with his distinction between northern and southern traditions). In Jeremiah 7 (a Deuteronomistic edited pericope) Jeremiah's reference to Shiloh is not sympathetic to the Levites. Jeremiah 33:14-18 therefore contrasts with Jeremiah 7 in advocating the restoration of the Levitical priesthood - probably an emphasis that would be somewhat foreign to Jeremiah himself.

\section{SUMMARY AND INFERENCE}

In the foregoing pages I have attempted to explain the absence of Jeremiah 33:14-26 in the LXX in terms of the hypothesis that the Masoretic text is a second edition of the Hebrew text of Jeremiah and that the Septuagint is based on a Hebrew Vorlage. It explained the longer text of the MT in terms of additions in the post-exilic era. A comparison of the two pericopes indicated that the expectation in Jeremiah 33:14-18 was a more general one with greater emphasis on Jerusalem and the survival of the realm (and hence of the people), and with an heir of David and a Levitical priest as permanent elements of an ordered future society. In both these eschatological pericopes, it is Yahweh who raises up the future order. It also appeared that Jeremiah 33:14-18 should perhaps be linked with the conflict between the disenfranchised Levites and the Zadokites who displaced them, and dated to the late exilic or early post-exilic period.

Our comparison made it clear that Jeremiah 33:14-16 was based on Jeremiah 23:5-6. The latter probably arose from Jeremiah's disappointment in the kings of Judah and may well have been written to relieve the dissonance between his expectation of how a king should act and the dismal reality.

Although the prophecy in Jeremiah 23:5-6 should be seen as an expectation for the future, some of Jeremiah's followers probably looked for its speedy fulfilment during the Exile itself. Some may even have taken the pronouncement to refer to

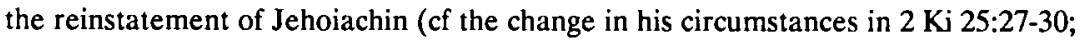
Jr 52:31-34), though no concrete evidence exists. The exact circumstances are unknown, but it is possible to see in Jeremiah 33:14-16 a reinterpretation of 
Jeremiah 23:5-6, which had not yet been fulfilled. The fall of Jerusalem brought a radical change of circumstances after the writing of Jeremiah 23:5-6. Little hope remained of a Davidic heir to the throne. Though this forms no part of my argument, Jeremiah 33:14-16 might even be understood as relieving the dissonance after the disappearance from the scene of Zerubbabel, to whom the fulfilment of the Davidic promise had been linked. Jeremiah 33:14-18 reinterprets Jeremiah 23:5-6 by generalising it, widening the perspective and shifting the emphasis (eg from the king to the city, and adding the correction of a legitimate heir of David and a legitimate Levitical priest). It is a deliberate attempt to counteract the doubt expressed in Jeremiah 33:24 inter alia. The same broadening of motives from the narrower (e $\mathrm{g}$ the king in $\mathrm{Jr}$ 23:5-6) to a bigger variety (e $\mathrm{g}$ king and cultic community in $\mathrm{J}_{\mathrm{r}} 33: 14-18$ ) is detectable in other prophecies as well (cf Is 28:5; 33:17, 21; Ezk 48; Carroll 1979:215). An attempt is made in the process to explain the non-fulfilment of Jeremiah 23:5-6 and to resolve the dissonance it creates. Carroll (1982:47-58) uses the term 'eschatological delay' and indicates the reaction and the attempts to explain it. The point at issue - for the prophets and presumably for the prophetic tradition - is the people's attitude to the future. The purpose of Jeremiah 33:14-26 is probably to open up possibilities of future fulfilment but presumably also to console and strengthen people who depended on the grace of Yahweh. The approach might be described as follows: 'Dissonance theory is helpful, not so much as an explanation of events, but rather as a way to think about problems' (Carroll 1979:103). My purpose too, was not so much to give final answers but to use an approach which, in my opinion, is conducive to research.

It became clear in the process that the traditions in the book of Jeremiah are flexible in their approach to the prophetic pronouncements. We may speak, in a sense, of both continuity and discontinuity in the actualisation and reinterpretation of the prophecy. Our discussion of the two parallels also served to indicate the long tradition and growth process underlying the book of Jeremiah.

These traditions respected the prophetic word but also took a flexible approach in the light of changing circumstances. The prophetic word had to be relevant to each period in turn.

\section{Works cited}

Ackroyd, P R 1972. Exile and restoration. London: SCM.

Blenkinsopp, J 1984. A history of prophecy in Israel. London: SPCK.

Carroll, R P 1979. When prophecy failed. London: SCM.

--- 1981. From chaos to covenant. London: SCM. 
--- 1982. Eschatological delay in the prophetic tradition? $Z A W 94,48-58$.

--- 1984. Prophecy dissonance, and Jeremiah 26, in L G Perdue and B W Kovacs (eds), $A$ prophet to the nations. Indiana: Eisenbrauns.

--- 1986. Jeremiah. London: SCM.

De Vaux, R 1968. Ancient Israel. London: Darton, Longman \& Todd.

Fohrer, G 1969. Einleitung in das Alte Testament. 11. Aufl. Heidelberg: Quelle \& Meyer.

Hanson, P D 1979. The dawn of apocalyptic. Philadelphia: Fortress.

-- 1985. Apocalyptic literature, in D A Knight \& G M Tucker, The Hebrew Bible and its modern interpreters. Philadelphia: Fortress.

Janzen, J G 1973. Studies in the text of Jeremiah. Massachusetts: Harvard University Press.

Polk, T 1979. The Levites in the Davidic-Solomonic Empire. Studia Biblica et Theologica 9, 1-10.

Rudolph, W 1968. Jeremia 3. Aufl. Tübingen: Mohr.

Schmidt, W H 1982. Einführung in das Alte Testament. Berlin: De Gruyter.

Smend, R 1981. Die Entstehung des Alten Testaments. Stuttgart: Kohlhammer.

Soderlund, S 1985. The Greek text of Jeremiah: $A$ revised hypothesis. Sheffield: JSOT Press.

Steck, O H 1968. Das Problem theologischer Strömungen in nach-exilischer Zeit. EvTh 28, 445-458.

Thompson, J A 1980. The book of Jeremiah. Grand Rapids: Eerdmans.

Tov, E 1978. The nature of the Hebrew Text underlying the LXX: A survey of the problems. JSOT 7, 52-68.

-- 1985. The literary history of the book of Jeremiah in the light of its textual history, in J H Tigay (ed), Emperical models for Biblical criticism. Philadelphia: Fortress.

Van Selms, A 1972. Jeremia. Nijkerk: Callenbach.

Weippert, H 1981. Schöpfer des Himmels und der Erde. Stuttgart: Verlag Katholisches Bibelwerk.

Weiser, A 1969. Das Buch Jeremiah. 6. Aufl. Göttingen: Vandenhoek.

Wessels, W J 1985. Jeremia se opvatting oor die koningskap: 'n Ontleding van Jeremia 21:1-23:8. DTh-Thesis, Pretoria: University of South Africa.

Wildberger, H 1972. Jesaja 1-12. Neukirchen: Neukirchener Verlag.

Wilson, R R 1980. Prophecy and society in Ancient Israel. Philadelphia: Fortress. 